\title{
ANGKA KUMAN PADA TEMPAT TIDUR DI RUMAH SAKIT DAERAH MADANI PALU
}

\author{
Bacterial numbers on ward beds in Hospital of Madani Palu
}

\author{
Monica Cecilia Parobe ${ }^{1}$, Novarianti ${ }^{1}$, Christine ${ }^{1}$ * \\ ${ }^{1}$ Jurusan Sanitasi Poltekkes Kemenkes Palu \\ *email korespondensi: christinekromoprawiro@gmail.com
}

\begin{abstract}
ABSTRAK
Lingkungan rumah sakit yang kurang baik akan memungkinkan terjadinya penularan penyakit yang dapat berpengaruh terhadap kesehatan masyarakat dalam lingkungan rumah sakit tersebut. Oleh karena itu, pelayanan sanitasi rumah sakit perlu diselenggarakan dalam rangka menciptakan kondisi lingkungan rumah sakit yang nyaman dan bersih, sehingga dapat mendukung usaha penyembuhan penderita dan dapat mencegah terjadinya penularan infeksi nosokomial dilingkungan rumah sakit. Tujuan penelitian ini diketahuinya angka kuman pada tempat tidur rawat inap Rumah Sakit Madani Daerah Palu. Metode penelitian deskriptif dengan pendekatan observasi, populasi penelitian ini adalah semua tempat tidur di ruang perawatan Melon, Jambu, Rambutan, Nangka, Semangka, dan Markisa di Rumah Sakit Daerah Madani Kota Palu. Sampel penelitian ini adalah sebagian tempat tidur pada ruangan Melon 10, Jambu 10, Rambutan 10, Nangka 9, Semangka 7, dan Markisa 4, di ambil secara acak sederhana. Hasil penelitian yang telah dilakukan pada tempat tidur di ruang perawatan Melon, Jambu, Rambutan, Nangka, Semangka, dan Markisa, menunjukkan angka kuman tidak memenuhi syarat yaitu $>10 \mathrm{koloni} / \mathrm{cm}^{2}$. Sehingga dapat disimpulkan angka kuman pada tempat tidur ruang perawatan Rumah Sakit Daerah Madani Palu tidak memenuhi syarat.
\end{abstract}

\section{Kata kunci : Angka kuman, tempat tidur, rumah sakit}

\section{ABSTRACT}

The unhygienic environment of the hospital will allow the transmission of diseases that can affect public health in that hospital. Therefore, hospital sanitation services need to be organized in order to create a comfortable and clean hospital environment, so that it can support efforts to cure and prevent the transmission of nosocomial infections in the hospital environment. The purpose of this study was to determine the number of germs on the inpatient bed of District Madani Hospital of Palu. The method of this study used descriptive with observational approach. The study population was all inpatient beds in Melon, Jambu, Rambutan, Nangka, Semangka, dan Markisa treatment rooms at Madani Regional Hospital of Palu. The sample of this study was a part of the impatient bed in rooms of Melon 10, Jambu 10, Rambutan 10, Rambutan 9, Semangka 7, and Markisa 4, which were taken by simple random sampling. The results showed that the number of germs did not meet the requirements of $>10$ colonies $/ \mathrm{cm}^{2}$. So it can be concluded that the number of germs on the inpatient bed of the treatment room at the Palu Madani Regional Hospital does not meet the requirements.

Keywords : Germ number, bed, hospital

\section{PENDAHULUAN}

Rumah sakit merupakan sarana pelayanan kesehatan, tempat berkumpulnya orang sakit maupun orang sehat, atau dapat menjadi tempat penularan penyakit serta memungkinkan terjadinya pencemaran lingkungan dan gangguan kesehatan. Setiap kegiatan yang dilakukan di rumah sakit sangat rentan untuk terjadinya penularan penyakit karena faktor lingkungan yang sangat mendukung, kuman penyakit dapat hidup dan berkembang di lingkungan rumah sakit seperti: udara, air, lantai, makanan dan benda-benda medis maupun non medis (jendela, tempat tidur, tirai, pintu dan handel pintu) ${ }^{(5)}$. 
Berdasarkan hasil penelitian Prafitri (2016) ditemukannya angka kuman pada handle pintu yaitu $872,5 \mathrm{koloni} / \mathrm{cm}^{2}$ di ruang perawatan mawar kelas III RSUD Prof. Dr. Margono Soekarjo Purwokerto ${ }^{(11)}$. Lingkungan yang tidak higienis dapat menjadi sumber terbaik bagi organisme patogen untuk hidup. Udara, air dan makanan dapat terkontaminasi dan ditransmisikan ke pasien lewat perawatan kesehatan. Dinding, lantai, jendela, tempat tidur, kamar mandi, toilet, dan perangkat medis lainnya juga dapat menjadi tempat hidup organisme pathogen ${ }^{(8)}$.

Lingkungan rumah sakit yang kurang baik akan memungkinkan terjadinya penularan penyakit yang dapat berpengaruh terhadap kesehatan masyarakat dalam lingkungan rumah sakit tersebut. Oleh karena itu, pelayanan sanitasi rumah sakit perlu diselenggarakan dalam rangka menciptakan kondisi lingkungan rumah sakit yang nyaman dan bersih, sehingga dapat mendukung usaha penyembuhan penderita dan dapat mencegah terjadinya penularan infeksi nosokomial dilingkungan rumah sakit ${ }^{(7)}$.

Infeksi nosokomial dapat disebabkan oleh bakteri, virus, jamur, atau parasit yang berasal dari dalam tubuh penderita sendiri maupun berasal dari sumber eksogin, yaitu dari lingkungan, dari alat-alat kesehatan (jarum suntik, pelarut obat suntik), alat bantu pernapasan, kateter vena, alat transfusi dan perlengkapan rumah sakit lainnya (meja, kursi, tempat tidur) yang tercemar. Selain itu sumber infeksi penting lainnya adalah petugas rumah sakit (dokter, dokter gigi, perawat, bidan, dan petugas perawatan lainnya), dari penderita lain yang sedang dirawat di rumah sakit, atau dari keluarga penderita yang berkunjung ke rumah sakit ${ }^{(13)}$. Berdasarkan hasil penelitian Prafitri (2016) ditemukannya angka kuman pada handle pintu yaitu $872,5 \mathrm{koloni} / \mathrm{cm}^{2}$ di ruang perawatan mawar kelas III RSUD Prof. Dr. Margono Soekarjo Purwokerto ${ }^{(11)}$.

Penelitian lain oleh Oluwagbemiga (2017) di rumah sakit di Nigeria Selatan pada sampel 120 permukaan peralatan di 12 bangsal menunjukkan permukaan peralatan merupakan jalur utama untuk transmisi infeksi nosokomial di fasilitas perawatan kesehatan. Angka kuman $(1038,0 \times 105 \mathrm{cfu})$ memuncak di ICU tetapi paling rendah $(446,9 \times 105 \mathrm{CFU})$ di bangsal pria. Angka kuman $(\times 105 \mathrm{CFU})$ dari 234,7 ,
199,7 dan 67,0 masing-masing diukur pada keran ICU, gagang pintu dan EKG. Mesin diatomi teater, mesin anestesi dan lampu operasi memiliki angka kuman $(\times 105 \mathrm{CFU})$ masing-masing 40,0, 85,0 dan 109,0 ${ }^{(10)}$.

Dipilihnya ruang perawatan karena ruang perawatan merupakan salah satu ruangan yang memungkinkan terjadinya pertumbuhan kuman. Dari hasil wawancara dengan kepalakepala ruangan, bahwa setelah pasien keluar dari ruang perawatan, tempat tidur yang digunakan jarang di bersihkan, yang dibersihkan hanya laken.

Seringkali Rumah Sakit kehilangan citranya dan berubah fungsi menjadi tempat yang memberikan kesan tidak teratur, kotor dan tidak nyaman terutama menyangkut sanitasi lingkungan rumah sakit. Rumah Sakit Daerah Madani merupakan salah satu rumah sakit yang ada di Kota Palu. Hasil penelitian yang dilakukan oleh Aminudin dan Adiono (2015), masih ada responden yang menilai mutu pelayanan kesehatan di ruang rawat inap di Rumah Sakit Daerah Madani kurang baik ${ }^{(2)}$.

Melihat besarnya peran Rumah Sakit Daerah Madani dalam pelayanan kesehatan bagi masyarakat, maka penulis tertarik mengadakan penelitian di Rumah Sakit Madani Palu yang bertipe $\mathrm{C}$ yang berkaitan dengan Angka Kuman Pada Tempat Tidur di Rumah Sakit Daerah Madani Palu. Oleh karena itu, tujuan penelitian ini adalah diketahuinya angka kuman pada tempat tidur di ruang rawat inap Melon, Jambu, Rambutan, Nangka, Semangka, dan Markisa di rumah sakit daerah Madani Palu.

\section{METODE PENELITIAN}

Penelitian ini merupakan suatu penelitian deskriptif dengan pendekatan observasi, dilaksanakan pada tanggal 7 April-5 Mei 2018 di Rumah Sakit Daerah Madani Kota Palu dan pemeriksaan di Laboratorium Poltekkes Kemenkes Palu Jurusan Kesehatan Lingkungan. Populasi penelitian ini sebanyak 97 tempat tidur yang ada di ruang perawatan Melon, Jambu, Rambutan, Nangka, Semangka, dan Markisa. Besar sampel dihitung dengan menggunakan rumus Slovin dan diperoleh 50 tempat tidur. Pengambilan sampel dilakukan secara acak sederhana hingga diperoleh tempat tidur di ruang rawat inap ruangan Melon 10, Jambu 10, Rambutan 10, Nangka 9, Semangka 
7, dan Markisa 4.

Alat yang digunakan dalam penelitian ini adalah: coloni counter, lampu spirtus, termos es dan gelas kimia. Bahan yang digunakan dalam penelitian ini adalah sampel pemeriksaan berupa hasil usap tempat tidur, kapas lidi steril, phospat buffer saline 10\%, PCA (Plate Count Agar), pengencer, alkohol $70 \%$, handscoon.

Pada setiap tempat tidur pasien, diambil sebanyak 4 titik, karena dari 4 titik dianggap mewakili angka kuman dari tempat tidur tersebut, bagian titik yang diambil yaitu pagar pembatas bagian kiri dan kanan, pembatas kepala dan pembatas kaki, pengambilan titik tersebut karena bagian itulah yang sering disentuh oleh pengunjung atau penjaga pasien.

Banyaknya angka kuman pada sampel yang diperiksa lalu dibandingkan dengan persyaratan kesehatan lingkungan rumah sakit. Kondisi yang memenuhi syarat adalah apabila angka kuman $\leq 10 \mathrm{CFU} / \mathrm{cm}^{2}$ dan dikatakan tidak memenuhi syarat apabila angka kuman $>10 \mathrm{~cm}^{2(6)}$.

\section{HASIL}

Rumah Sakit Daerah Madani Provinsi Sulawesi Tengah adalah Rumah Sakit Daerah Madani Tipe B khusus dengan kapasitas 240 tempat tidur yang terdiri dari kelas utama (VIP), kelas I, kelas II dan kelas II. Berdasarkan penelitian, diperoleh hasil sebagai berikut :

Tabel 1. Angka Kuman pada Tempat Tidur Pasien berdasarkan Angka Kuman di RSUD Madani Palu Tahun 2018

\begin{tabular}{lcc}
\hline Ruangan & $\begin{array}{c}\text { Rata-rata } \\
\text { angka kuman } \\
\text { (CFU/cm² }\end{array}$ & Keterangan \\
\hline Rambutan & 3.776 & $\begin{array}{c}\text { Tidak } \\
\text { memenuhi syarat }\end{array}$ \\
\hline Melon & 1.692 & $\begin{array}{c}\text { Tidak } \\
\text { memenuhi syarat }\end{array}$ \\
\hline Jambu & 3.864 & $\begin{array}{c}\text { Tidak } \\
\text { memenuhi syarat }\end{array}$ \\
\hline Markisa & 4.863 & $\begin{array}{c}\text { Tidak } \\
\text { memenuhi syarat }\end{array}$ \\
\hline Nangka & 6.638 & $\begin{array}{c}\text { Tidak } \\
\text { memenuhi syarat }\end{array}$ \\
\hline Semangka & 2.588 & $\begin{array}{c}\text { Tidak } \\
\text { memenuhi syarat }\end{array}$ \\
\hline
\end{tabular}

Sumber : Data Primer, 2018
Pemeriksaan angka kuman pada tempat tidur rawat inap di Rumah Sakit Madani menunjukkan hasil $>10$ koloni $/ \mathrm{cm}^{2}$. Berdasarkan Kepmenkes RI No. 1204 Tahun 2004 tentang persyaratan kesehatan lingkungan rumah sakit, bahwa angka kuman di ruang perawatan di standarkan 10 koloni, sehingga nilai angka kuman ruangan Melon, Jambu, Rambutan, Nangka, Semangka, dan Markisa belum memenuhi syarat.

\section{PEMBAHASAN}

Berdasarkan hasil penelitian, terdapat perbedaan total kuman yang signifikan serta angka kuman yang melebihi indeks angka kuman berdasarkan Kepmenkes No. 1204 tahun 2004. Hal ini dapat dipengaruhi oleh laju ventilasi, padatnya orang dan kegiatan orangorang yang menempati ruangan tersebut. Angka kuman juga dipengaruhi oleh suplai nutrisi, suhu untuk pertumbuhan, kelembaban, dan pencahayaan. Hal ini sesuai dengan penelitian Setyaningsih, dkk (1998) dimana suhu dan kelembaban mempengaruhi angka kuman ${ }^{(12)}$

Angka kuman pada tempat tidur berbeda-beda. Angka kuman pada ruangan Nangka merupakan yang paling tinggi, dikarenakan pada saat pengambilan sampel hampir semua tempat tidur diisi oleh pasien ditambah lagi dengan pengunjung maupun keluarga pasien yang menginap diruangan tersebut. Pagar pembatas bagian kiri dan kanan, pembatas kepala dan pembatas kaki adalah bagian yang sering disentuh oleh pengunjung atau penjaga pasien. Hal ini merupakan salah satu penyebab tingginya angka kuman pada tempat tidur, sedangkan pada ruangan lainnya tidak semua tempat tidur terisi oleh pasien.

Penyebaran kuman melibatkan media lingkungan seperti udara dan vektor sebagai perantara atau kendaraan. Mikroorganisme patogen di udara, termasuk bakteri, virus, jamur dan parasit, dapat menyebabkan infeksi nosokomial. Di rumah sakit, infeksi ini dapat terjadi pada seseorang karena tertular oleh mikroorganisme dari orang lain atau oleh flora normal dari dirinya sendiri melalui persinggungan dengan makanan, udara, atau benda-benda yang tidak steril. Infeksi ini cenderung berjangkit secara epidemi, muncul 
dengan eksplosif, dan menyerang orang dalam waktu singkat. Penelitian Londok (2015) di Ruang ICU RSUP Prof. DR. R. D. Kandou Manado menunjukkan adanya pertumbuhan bakteri di tempat tidur, yaitu Serratia rubidaea, Kokus gram negatif dan Staphylococcus $s p^{(9)}$.

Hasil penelitian Wikansari (2012) di ruang perawatan bedah RSUDP Dr. Wahidin Sudirohusodo Makassar ditemukan S. aureus, kuman penyebab utama infeksi nosokomial yang berasal dari saluran pernapasan bagian atas. Kuman ini ditemukan pada tangan, hidung, dan tenggorokan perawat yang dapat berperan sebagai sumber penularan. Selain $S$. aureus ditemukan juga beberapa kuman lain seperti Pseudomonas sp, E.coli, Enterobacter $s p$, Proteus sp, Klebsiella sp, dan Bacillus sp. Hasil penelitian tersebut menunjukkan bahwa rumah sakit merupakan tempat penyebaran kuman, terutama dari orang sakit atau carrier ke orang sehat (dari pasien ke petugas atau dari petugas ke pasien dan dari pasien ke pengunjung atau sebaliknya) (14). Penelitian Asnul (2018) di ruang ICU Rumah Sakit Bhayangkara POLDA Bengkulu menunjukkan angka kuman secara keseluruhan adalah $26,42 \times 103 \mathrm{CFU} / \mathrm{cm} 2$ dengan rincian $19,6 \times 103$ $\mathrm{CFU} / \mathrm{cm} 2$ pada dinding, $28,8 \times 103 \mathrm{CFU} / \mathrm{cm} 2$ pada lantai dan $30,87 \times 103 \mathrm{CFU} / \mathrm{cm} 2$ pada tempat tidur. Hasil tersebut menunjukkan tingginya angka kuman pada tempat tidur ${ }^{(3)}$.

Berdasarkan hasil penelitian, penyebab tingginya angka kuman pada tempat tidur pasien dapat dikarenakan tempat tidur tidak dibersihkan, yang dibersihkan hanya laken. Padahal, perawatan tempat tidur pasien dapat dilakukan 1 kali atau dalam 1 bulan 3-4 kali, adalah dengan membersihkan debu dengan lap basah pada matras, dan membersihkan bagian sela-sela ranjang yang tidak terlihat agar terhindar dari debu. Membersihkan rel atau pegangan tempat tidur dengan disinfektan mengurangi beban bakteri intrinsik pada permukaan rel hingga 99\%, walaupun untuk bakteri stafilokokus dapat pulih dengan cepat (14). Saat tempat tidur tidak digunakan maka lebih baik ditutupi dengan kain atau plastik agar tidak kotor dan rusak ${ }^{(15)}$. Pembersihan tempat tidur dilakukan rutin untuk menghindari terjadinya kontaminasi kuman atau mikroorganisme dan infeksi nosokimial dari satu pasien ke pasien lain. Suatu tempat yang bersih, aman, dan nyaman dapat meningkatkan kemampuan pasien beristirahat dan tidur serta memiliki perasaan nyaman.

\section{KESIMPULAN DAN SARAN}

Berdasarkan hasil penelitian tentang angka kuman pada tempat tidur di Rumah Sakit Daerah Madani Palu, dapat disimpulkan bahwa angka kuman pada tempat tidur ruang perawatan Melon, Rambutan, Nangka, Semangka, Markisa dan Jambu tidak memenuhi syarat, yaitu $>10 \mathrm{koloni} / \mathrm{cm}^{2}$. Untuk itu, disarankan kepada pihak rumah sakit, petugas sanitasi perlu melakukan upaya bagi petugas kebersihan untuk membersihkan dengan cara membersihkan tempat tidur pasien secara rutin. Rumah sakit juga perlu melakukan pengawasan serta pengambilan sampel dan pemeriksaan kuman. Petugas juga harus lebih ketat dalam mengawasi jam besuk pasien.

\section{UCAPAN TERIMA KASIH}

Ucapan terima kasih disampaikan kepada Direktur Rumah Sakit Daerah Madani Palu yang telah memberikan izin sehingga penelitian ini dapat terlaksana, dan juga kepada seluruh petugas sanitasi yang telah membantu selama pelaksanaan penelitian.

\section{DAFTAR PUSTAKA}

1. Abdullah, Abdullah, M. T., \& Hakim, B. A. (2011). Lingkungan Fisik dan Angka Kuman Udara Ruangan di Rumah Sakit Umum Haji Makassar, Sulawesi Selatan. Kesmas Journal of Public Health, 206211.

2. Aminuddin; Adiono, Sugeng . (2017). Analisis Mutu Pelayanan Kesehatan di Ruang Rawat Inap Rumah Sakit Daerah Madani Provinsi Sulawesi Tengah. Poltekita: Jurnal Ilmu Kesehatan, 867934.

3. Asnul, Rahima, A. I., Enny, Nugraheni, S., Hilda, \& Taurina. (2018). Angka dan Pola Bakteri pada Dinding, Lantai, dan Tempat Tidur di Ruang Intensive Care Unit (ICU) Rumah Sakit Bhayangkara Polda Bengkulu. Bengkulu: Universitas Bengkulu.

4. Attaway, H. H., BS, S. F., Steed, L. L., Salgado, C. D., Michels, H. T., \& Schmidt, M. G. (2012). Intrinsic Bacterial 
Burden Associated With Intensive Care

Unit Hospital Beds: Effects Of Disinfection On Population Recovery And Mitigation Of Potential Infection Risk. American Journal of Infection Control, 907-912.

5. Febriyanti, C. W. (2012). Studi Komparasi Angka Kuman pada Handle Pintu Bangsal dan Ruang Administrasi di Rumah Sakit Umum Daerah Kebumen Tahun 2012. Semarang: Politeknik Kesehatan Kementerian Kesehatan Semarang.

6. Kementerian Kesehatan. (2004). Persyaratan Kesehatan Lingkungan Rumah Sakit. Jakarta.

7. Kementerian Kesehatan. (2010). Klasifikasi Rumah Sakit. Jakarta.

8. Khan, H. A., Baig, F. K., \& Mehboob, R. (2017). Nosocomial Infections: Epidemiology, Prevention, Control And Surveillance. Asian Pasific Journal of Tropical Biomedicine, 478-482.

9. Londok, P. V., Homenta, H., \& Buntuan, V. (2015). Pola Bakteri Aerob yang Berpotensi Menyebabkan Infeksi Nosokomial di Ruang ICU RSUP Prof. DR. R. D. Kandou Manado. e_Biomedik, 448-452.

10. Oluwagbemiga, A. O., Akinsete, S. J., \& Ana, G. R. (2017). Building Conditions And The Risk Of Nosocomial Infection From Microbial Contamination Of Hospital Appliances In A Health Care Facility. International Journal of Environmental Health Research, 264-275.

11. Prafitri, Indah Rahmi; Utomo, Budi. (2016). Studi Angka Kuman Handle Pintu di Bagian Ruang Perawatan Mawar Kelas III RSUD Prof. Dr. Margono Soekarjo Purwokerta Tahun 2016. Buletin Keslingmas, 278-396.

12. Setyaningsih, Yuliani; Widjajasena, Baju; Hanani, Yusniar; Purnami, Cahaya; Ginandjar, Praba. (1998). Inventarisasi Mikroorganisme Udara dalam Ruangan dengan Sistem Pendingin Sentral. Semarang: Universitas Diponegoro.

13. Soekiman, S. (2016). Infeksi Nosokomial di Rumah Sakit. Jakarta: Sagungseto.

14. Wikansari, N. (2012). Pemeriksaan Total Kuman Udara dan Staphylococcus aureus di Ruang Rawat Inap Rumah Sakit X Kota Semarang. Semarang: Universitas Diponegoro.

15. Yuniarsih, R. (2016). Housekeeping-I. Surabaya: Politeknik NSC Surabaya. 